\title{
Dissociation of increases in plasma insulin-like growth factor I and testosterone during the onset of puberty in bulls
}

\author{
R. Renaville ${ }^{1}$, S. Massart ${ }^{1,2}$, M. Sneyers ${ }^{1,2}$, M. Falaki ${ }^{1}$, N. Gengler ${ }^{1}$, \\ A. Burny ${ }^{1}$ and D. Portetelle ${ }^{2}$ \\ ${ }^{1}$ Department of Molecular Biology and Animal Physiology; and ${ }^{2}$ Department of Microbiology, Faculty of \\ Agronomy, 2, Passage des Déportés B-5030 Gembloux, Belgium
}

\begin{abstract}
The present study was conducted to examine the relationship between plasma concentrations of testosterone, insulin-like growth factor I (IGF-I) and IGF-binding proteins (IGFBPs) during puberty, in male calves treated with GnRH or testosterone propionate. Twelve male Holstein calves ( 10 weeks old) were assigned to the control group $(n=6)$, the GnRH-treated group $(n=3)$ or the testosterone-treated group $(n=3)$. For 8 weeks, the GnRH-treated group received a single i.v. injection of $\mathrm{GnRH}\left(0.5 \mu \mathrm{g} \mathrm{kg}^{-1}\right.$ body mass $)$ each day while the testosterone-treated group received an i.m. injection of testosterone propionate $\left(0.5 \mathrm{mg} \mathrm{kg}^{-1}\right.$ body mass) twice a day. The calves were studied until they were 200 days old. Hormone treatments were stopped one month after puberty was reached in the control group. Blood samples were collected every $30 \mathrm{~min}$ for $8 \mathrm{~h}$ every third day. Hormone concentrations were determined by radioimmunoassay. Western ligand blotting and immunoblotting, using monoclonal antibodies against IGFBP-2 and IGFBP-3, were used to characterize the IGF-binding proteins. In the control group, puberty occurred at about 120 days of age and was associated with an increase in concentrations of testosterone, IGF-I and IGFBP-3 and a decrease in concentration of IGFBP-2. In the GnRH-treated group, plasma testosterone remained low until 8 weeks after establishment of puberty in the control group (4 weeks after the end of treatment). In the testosterone-treated group, testosterone was high during the treatment period and then decreased to prepubertal values when treatment was stopped. Testosterone values increased again to reach postpubertal values 5 weeks after the end of hormone treatment. Nevertheless, independent of testosterone status, the profile of IGF-I and the IGFBPs in the GnRH- and testosteronetreated groups were parallel to that reported for the control group with the transition from prepubertal to adult values at about 120 days of age. In conclusion, concentrations of testosterone, IGF-I and IGFBP-3 increase together, but probably independently, during the onset of puberty in male calves.
\end{abstract}

\section{Introduction}

The onset of puberty has been shown to be a complex synergism between sex steroids and insulin-like growth factor I (IGF-I) in humans (Metzger et al., 1994), sheep (Lord et al., 1991) and in cattle (Renaville et al., 1993). During this period, testosterone is released episodically and plasma concentrations of IGF-I increase strikingly, concomitant with an increase in mean plasma concentration of testosterone. A positive correlation was noted between the concentrations of these two hormones for bull calves during this physiological step (Renaville et al., 1993). Moreover, as in humans (Smith et al., 1993), baboons (Crawford et al., 1994) and pigs (Lee et al., 1991a), in cattle, the transition from prepubertal to mature male is characterized by a marked increase in IGFBP-3 concentrations (Renaville et al., 1993).
However, information on the possible link between IGF-I and testosterone synthesis during this physiological step is contradictory. Jasper (1985), Harris et al. (1985) and Attie et al. (1990), in humans, and Lee et al. (1991b), in cattle, reported that sex steroids stimulate IGF-I concentrations directly at the time of puberty, while Crawford et al. (1993) concluded that the pubertal IGF-I surge in mice does not require androgens in either the pre- or postpubertal periods. In addition, Godfrey et al. (1992) demonstrated that treatment with testosterone propionate delays puberty and endogenous pulsatile release of testosterone in bull calves, while Ronayme ef al. (1993) described an increase in testosterone concentrations in prepubertal bulls treated continuously with GnRH.

In the study described here, prepubertal bull calves were treated with testosterone propionate or $\mathrm{GnRH}$ to determine whether IGF-I is dependent on the androgen surge at the onset of puberty. 


\section{Materials and Methods}

\section{Animals}

Twelve, spring-born (identical calving day), Holstein male calves (10 weeks old) were assigned to either the control group $(n=6)$ or groups treated with either GnRH $(n=3)$ or testosterone propionate $(n=3)$. The $6 \times 3 \times 3$ experimental design used in the present study is justified by the fact that all data have been evaluated by comparison with the age of the onset of pulsatile testosterone release in the control group. The large number of animals in the control group was judged necessary to characterize this physiological stage exactly.

Animals were fed with grass hay twice a day and a commercial allmash containing $130 \mathrm{~g}$ crude protein $\mathrm{kg}^{-1}$. Feed intake was controlled so that body mass gain was about $950 \mathrm{~g}$ day $^{-1}$; water was supplied ad libitum. All animals were kept in identical conditions. Daily room temperature $\left(18^{\circ} \mathrm{C}\right)$ and daylength ( $16 \mathrm{~h}$ light: $8 \mathrm{~h}$ dark) were constant. Initial mean live masses were $74.4 \pm 4.8 \mathrm{~kg}$ for the control group, $75.9 \pm 3.2 \mathrm{~kg}$ for the GnRH-treated group and $73.1 \pm 5.9 \mathrm{~kg}$ for the testosterone-treated group.

\section{Experimental design}

For a period of 8 weeks, the GnRH-treated group received a daily i.v. injection of $\mathrm{GnRH}\left(0.5 \mu \mathrm{g} \mathrm{kg}^{-1}\right.$ body mass; Sigma, St Louis, MO) in $0.5 \mathrm{ml}$ saline and the testosterone-treated group was given an i.m. injection of testosterone propionate $\left(0.5 \mathrm{mg} \mathrm{kg}{ }^{-1}\right.$ body mass; Sigma) in $0.5 \mathrm{ml}$ saline twice a day. Control calves received an i.m. injection of saline $(0.5 \mathrm{ml})$ daily. Animals were studied between 70 and 200 days of age (day $0=$ birth). Hormone treatments were stopped one month after puberty was achieved in the control group. Puberty was taken as the time when more than two successive values of testosterone were greater than $2 \mathrm{ng} \mathrm{ml}^{-1}$ (Renaville et al., 1993).

Blood samples $(5 \mathrm{ml})$ were taken from the jugular vein via a polyurethane catheter into heparinized tubes at $30 \mathrm{~min}$ intervals from $08: 00 \mathrm{~h}$ to $17: 00 \mathrm{~h}$ every third day. Samples were stored immediately at $4^{\circ} \mathrm{C}$ and then centrifuged at $1800 \mathrm{~g}$ for $10 \mathrm{~min}$. Plasma was separated and stored at $-20^{\circ} \mathrm{C}$ until it was used in the hormone and binding-protein assays.

\section{Iodination procedure}

The recombinant bovine IGF-I (rbIGF-I; batch GTS-1) used as iodinated tracer (in radioimmunoassay and western ligand blotting) and as standard (in radioimmunoassay) was kindly donated by Monsanto (St Louis, MO). The hormone was labelled with $\left.\mathrm{Nal}{ }^{125} \mathrm{I}\right]$ by the chloramine $\mathrm{T}$ method (Parker, 1990). ${ }^{125}$ I-labelled rbIGF-I was separated from free iodine using a Centricon-3 microconcentrator as recommended by the manufacturer (Amicon Division, Beverly, MA). The specific activity was $70 \mu \mathrm{Ci} \mu \mathrm{g}^{-1}$.

Tritiated testosterone $\left(\left[1,2,6,7{ }^{3} \mathrm{H}\right]\right.$ testosterone, batch TRK 402 , specific activity $80-105 \mathrm{Ci} \mathrm{mmol}^{-1}$ ) was purchased from Amersham International (Amersham, Bucks).
Production of monoclonal antibodies against bovine IGF binding protein (IGFBP) -2 and -3

Anti-bovine IGFBP-2 and IGFBP-3 monoclonal antibodies were produced in our laboratory (Portetelle et al., 1995). Briefly, ten-week-old female BALB/c mice were immunized with $100 \mu \mathrm{g}$ recombinant fusion protein bovine IGFBP-2 (or -3)maltose binding protein (MBP) in incomplete Freund's adjuvant $(0.10 \mathrm{ml}$ total volume) equally distributed into the rear footpads. Fourteen days after immunization, mice were bled as recommended by Mirza et al. (1987) and the draining lymph nodes (popliteal and inguinal) were removed and pooled for fusion as described by Bruck et al. (1982) with the modification that NSO murine cells were used as myeloma partner.

Specific antibody-producing hybridomas were identified by differential indirect enzyme-linked immunosorbent assays (ELISA) tests using recombinant proteins IGFBP-MBP or MBP adsorbed onto the wells (Portetelle et al., 1989). Positive hybridomas were cloned twice in soft agar, grown on Pristaneprimed $B A L B / C$ mice and then purified by ion-exchange chromatography. In the present study, the 7B5 anti-IGFBP-3 (isotype $\operatorname{lgGI}$ ) monoclonal antibody and the $8 \mathrm{G} 10$ antiIGFBP-2 (isotype IgGI) monoclonal antibody were used in the immunoblot studies.

\section{Hormone determination}

Testosterone was determined by radioimmunoassay as described by Renaville et al. (1983). The minimum detectable dose of testosterone was $0.1 \mathrm{ng} \mathrm{ml}^{-1}$. The intra- and interassay coefficients of variation were $4.8 \%$ and $10.7 \%$, respectively, for the low standard concentration $\left(0.8 \mathrm{ng} \mathrm{ml}^{-1}\right)$ and $2.1 \%$ and $6.1 \%$, respectively, for high standard concentration (10 $\mathrm{ng} \mathrm{ml}^{-1}$ ).

The radioimmunoassay for IGF-I in bull plasma was performed according to the method described by Lemal et al. (1989) and adapted by Renaville et al. (1993). In this method, as reported by Breier et al. (1991), a cryoprecipitation step is used to eliminate aggregated proteins in plasma extracts. Briefly, after acid-ethanol extraction $(87.5 \%$ ethanol and $12.5 \% \mathrm{HCl}$ mol $\left.1^{-1} \mathrm{v} / \mathrm{v}\right)$, an aliquot of the supernatant was neutralized with $0.855 \mathrm{~mol}$ Tris base $\mathrm{I}^{-1}$ at a ratio of $5: 2$. The samples were stored at $-20^{\circ} \mathrm{C}$ for $1 \mathrm{~h}$ and then centrifuged at $3000 \mathrm{~g}$ for $30 \mathrm{~min}$ at $4^{\circ} \mathrm{C}$. The supernatant was decanted into fresh test tubes and used in the radioimmunoassay. The minimum

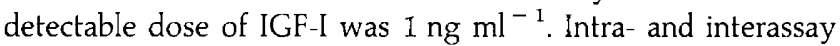
coefficients of variation were $12 \%$ and $16 \%$, respectively, for the low standard concentration $\left(25 \mathrm{ng} \mathrm{ml}^{-1}\right.$ ) and $6.5 \%$ and $9 \%$, respectively, for the high standard concentration (250 $\mathrm{ng} \mathrm{ml}^{-1}$ ).

\section{Western ligand blotting}

Western ligand blotting was performed to evaluate plasma IGFBPs following the method described by Renaville et al. (1993). Briefly, I $\mu$ l of SDS-denatured plasma was applied to a $4 \%$ stacking gel and electrophoresis was performed through a $12.5 \%$ polyacrylamide gel. Prestained ${ }^{14} \mathrm{C}$-labelled molecular weight markers (Amersham) were run in parallel lanes. The gels were then soaked in Towbin buffer $\left(25 \mathrm{mmol}\right.$ Tris $1^{-1}$, 
$192 \mathrm{mmol}$ glycine $\mathrm{l}^{-1}, 20 \%(\mathrm{v} / \mathrm{v})$ methanol, $\left.\mathrm{pH} 8.3\right)$ and proteins were blotted onto nitrocellulose sheets (Hybond-C, Amersham). Electrophoresis and electrotransfer were performed using the Mini-Protean II system (Bio-Rad, Richmond, CA). After saturation, membranes were incubated with ${ }^{125}$ I-labelled rbIGF-I (4000 c.p.m. $\mathrm{cm}^{-2}$ blot) overnight at $4^{\circ} \mathrm{C}$. The membranes were then washed, air-dried and exposed to Kodak X-Omat AR films (Rochester, NY) for 2-4 days at $-70^{\circ} \mathrm{C}$.

Autoradiograms were scanned using a Sharp JX 325 scanner and band intensities were analysed with IMAGEMASTER ID software (Pharmacia, Uppsala). A plasma pool was used as internal standard.

\section{Immunoblotting}

Plasma samples $(1.5 \mu \mathrm{l})$ were denatured by SDS with dithiothreitol as reducing agent and then applied to a $4 \%$ stacking gel; electrophoresis was performed through a $12.5 \%$ SDS-polyacrylamide gel, and blotted onto Immobilon sheet. Electrophoresis and electrotransfer were performed using the Mini-Protean II System (Bio-Rad).

Membranes were saturated for $I \mathrm{~h}$ at room temperature with a $10 \%$ defatted milk solution in Tris saline buffer $(10 \mathrm{mmol}$ Tris- $\mathrm{HCl} 1^{-1}, 150 \mathrm{mmol} \mathrm{NaCl} 1^{-1}, \mathrm{pH} 7.4$ ), and then incubated overnight at $4^{\circ} \mathrm{C}$ with monoclonal antibody (mAb) 7B5 $\left(2.4 \mu \mathrm{g} \mathrm{mi}^{-1}\right)$ or $\mathrm{mAb} 8 \mathrm{GiO}\left(2.1 \mu \mathrm{g} \mathrm{ml}{ }^{-1}\right)$ diluted in Tris saline buffer containing $0.1 \%(\mathrm{v} / \mathrm{v})$ Tween 20 . Membranes were washed three times in Tris saline buffer containing $0.1 \%$ Tween $20(\mathrm{v} / \mathrm{v})$, followed by incubation for $\mathrm{I} \mathrm{h}$ at room temperature with alkaline phosphatase coupled goat-anti-mouse antibody $\left(0.133 \mu \mathrm{g} \mathrm{ml}^{-1}\right.$; Promega, Leiden) in Tris saline buffer containing $0.1 \%$ Tween $20(\mathrm{v} / \mathrm{v})$. Membranes were washed four times in Tris saline buffer containing $0.1 \%$ Tween 20 , and alkalinephosphatase activity was revealed using NBT/BCIP substrate (KPL, Gaithersburg, MD).

Immunoblot membranes were scanned using a Sharp JX 325 scanner and band intensities were analysed with IMAGEMASTER iD software. A plasma pool was used as the internal standard.

\section{Statistical analyses}

Values are presented as means $\pm S D$. Between-group significance for parameters was assessed by analysis of variance using the GLM procedure of SAS software $\left(\mathrm{SAS}^{\mathrm{R}}, 1991\right)$. The following model was used:

$$
\Upsilon_{i j k}=\mu+T_{i}+P_{j}+(T P)_{i j}+e_{i j k}
$$

where $Y_{i j k}=$ observations for dependent variables of treatment $i$ during period $j$ on animal $k ; \mu=$ overall mean; $T_{i}=$ treatment effect $(i=1,2,3) ; P_{j}=$ period effect $(j=1,2,3, \ldots, 41,42,43)$; $(T P)_{i j}=$ fixed effect associated with interaction between treatment $i$ at period $j_{i}$ and $e_{i j k}=$ random residual effect for the $i$ th treatment and the $j$ th period.

Significant differences among means were determined by the $F$ test at $5 \%$ probability.

\section{Results}

\section{Changes in the concentrations of hormones during puberty}

In the control group, mean plasma concentrations of testosterone increased significantly $(P<0.001)$ from $105 \pm 5$ days old (mean value: $0.7 \pm 0.2 \mathrm{ng} \mathrm{ml}^{-1}$ ) to $120 \pm 10$ days $\left(2.1 \pm 0.3 \mathrm{ng} \mathrm{ml}^{-1}\right)$ (Fig. Ia). During this period, release of the hormone became pulsatile (values ranging from $0.2 \pm 0.1 \mathrm{ng}$ $\mathrm{ml}^{-1}$ to $4.3 \pm 1.9 \mathrm{ng} \mathrm{ml}^{-1}$ ), indicating that puberty had been reached. Mean concentrations of testosterone then increased progressively to day 160 (mean value: $3.1 \pm 0.8 \mathrm{ng} \mathrm{ml}^{-1}$ ), after which they remained relatively constant up to the end of the experimental period.

Hormone treatments had different effects on plasma testosterone concentrations. Injections of testosterone propionate immediately induced a significant $(P<0.001)$ increase in plasma testosterone; however, there was no daily episodic release, and concentrations remained higher $\left(7-9 \mathrm{ng} \mathrm{ml}^{-1} ; P<0.001\right)$ than in the control group during the treatment period (Fig. Ia). When testosterone treatment was discontinued (day 150; one month after the onset of puberty in the control group), mean plasma concentrations fell to prepubertal values $(0.5 \pm 0.2 \mathrm{ng}$ $\mathrm{ml}^{-1}$ ) in one week, and were lower than in the control group $(P<0.001)$ (Fig. 1a). It was only at $187 \pm 5$ days ( $33 \pm 7$ days after the end of treatment) that a pulsatile release of endogenous testosterone was osberved in this group and mean daily concentrations reached similar values to those in the controls. In the GnRH-treated group, a daily injection of GnRH affected the release of testosterone. From day 70 to day 110, mean values were low (range values: $0.3-0.7 \mathrm{ng} \mathrm{ml}^{-1}$ ) and no significant differences were observed with the control group. After day 110, while testosterone concentrations in the control group increased, values in the $\mathrm{GnRH}$ group, remained low until day $163 \pm 6\left(3.1 \pm 0.8 \mathrm{ng} \mathrm{ml}^{-1}\right.$ in the control group compared with $0.2 \pm 0.1 \mathrm{ng} \mathrm{ml}^{-1}$ in the GnRH group; $P<0.001$ ), from which time concentrations slowly increased, finally exhibiting pulsatile release and similar mean values to the control group $(P>0.05)$ at day $181 \pm 4$

During the experimental period, mean plasma concentrations of IGF-I exhibited a similar pattern in all groups. From day 70 to day 110 , mean plasma IGF-I values were relatively constant and no significant differences $(P>0.05)$ were observed between the experimental groups and the control group, with mean values for the period as follows: control group: $93 \pm 14 \mathrm{ng} \mathrm{ml}^{-1}$; testosterone-treated group: $76 \pm 17 \mathrm{ng}$ $\mathrm{ml}^{-1}$ and GnRH-treated group: $71 \pm 19 \mathrm{ng} \mathrm{ml}^{-1}$ (Fig. Ib). From day 110 to day 130 , a sharp increase $(P<0.001)$ in plasma concentrations was observed in all groups: $182 \pm 35 \mathrm{ng} \mathrm{ml}^{-1}$ in the control group; $156 \pm 24 \mathrm{ng} \mathrm{ml}^{-1}$ in the testosterone-treated group and $163 \pm 34 \mathrm{ng} \mathrm{ml}^{-1}$ in the GnRH-treated group. IGF-I concentrations in the control group then continued to increase, to reach values of about 250-300 ng ml $\mathrm{ml}^{-1}$ at the end of the experiment. In the two treatment groups, IGF-I concentrations increased more slowly and were below values for the control group between days 145 and $155(P<0.01)$. A second increase was observed between days 160 and 185 in the two treatment groups when values similar to those seen in the controls were reached. 
(a)

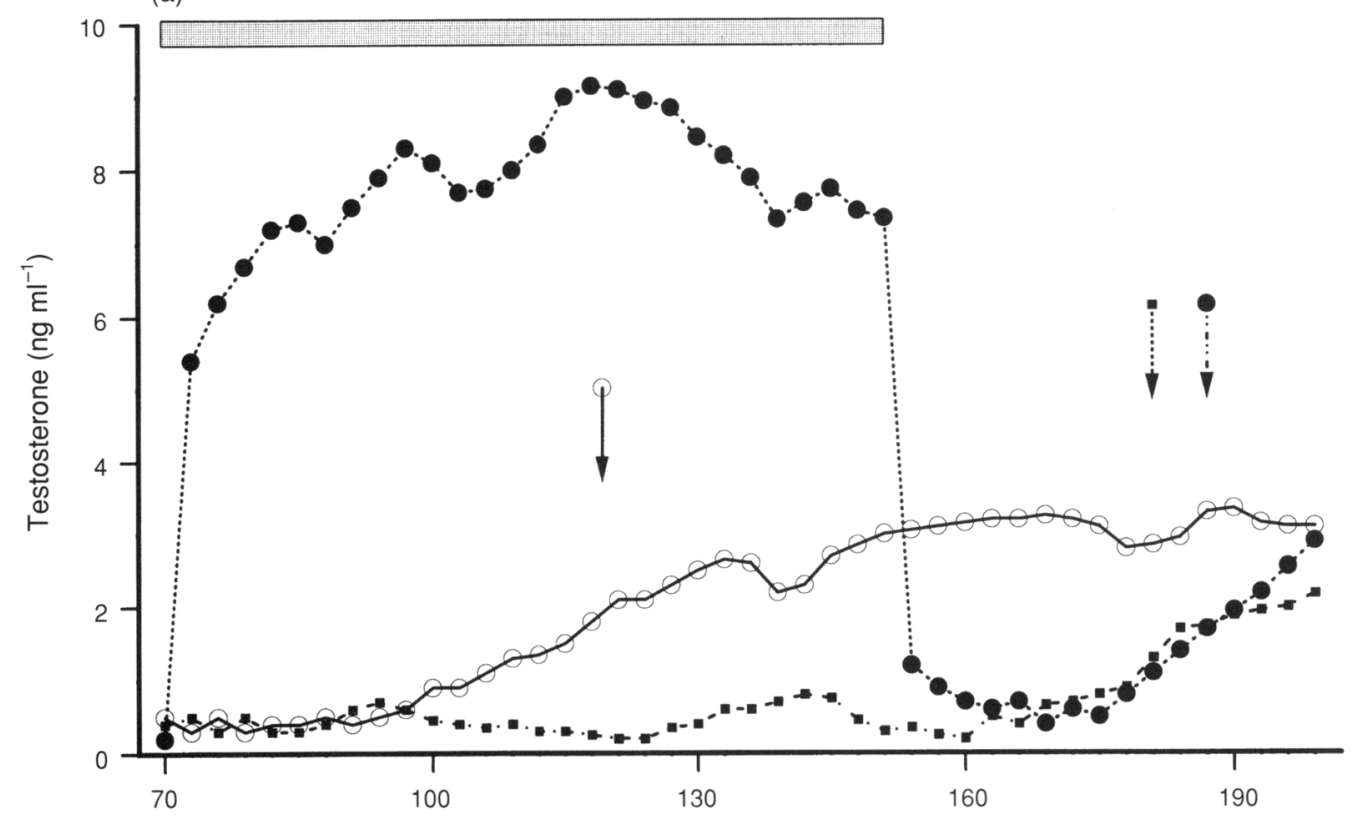

(b)

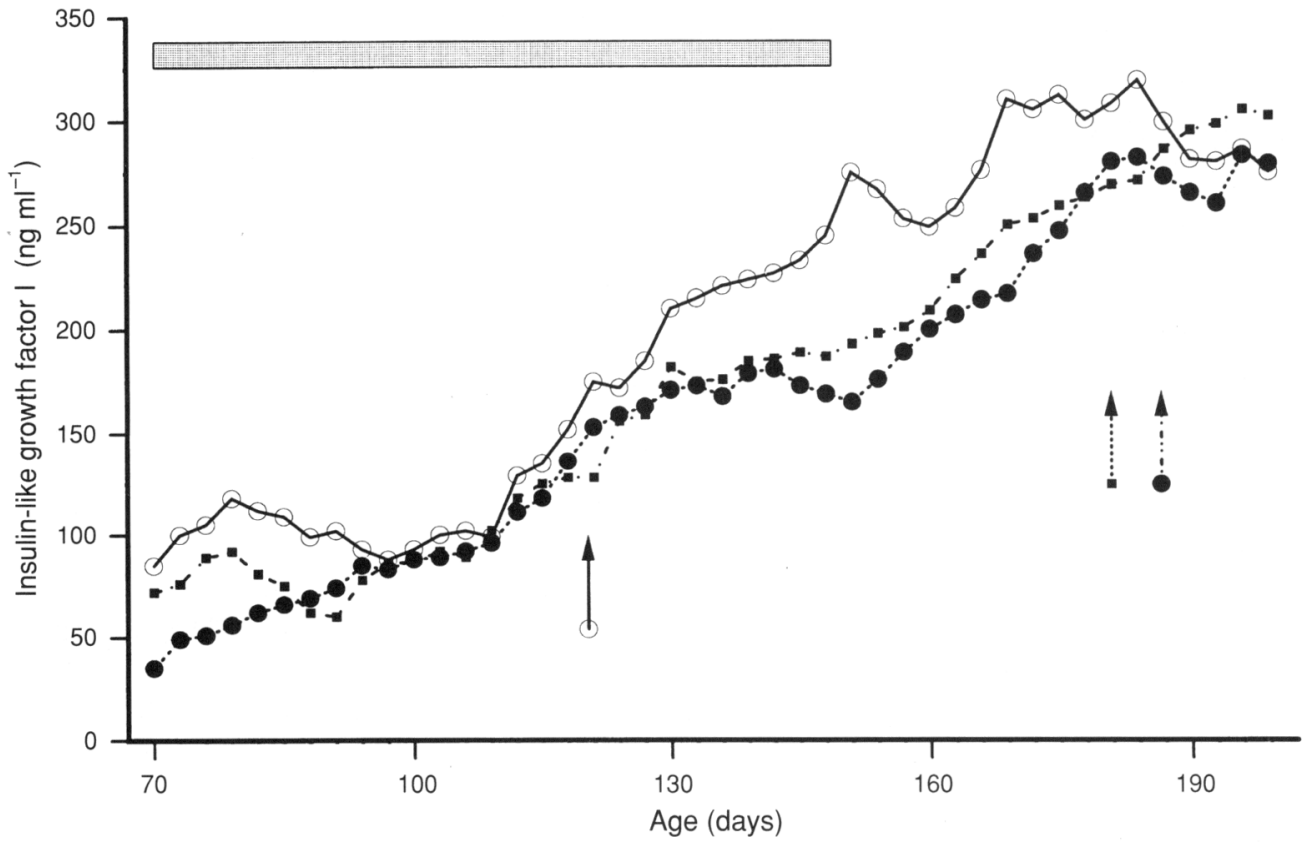

Fig. 1. Mean plasma concentrations of (a) testosterone and (b) insulin-like growth factor $I$ in $(O)$ control, (O) testosterone propionate-treated and ( $\bullet$ ) GnRH-treated bulls during the onset of puberty. ( $\square$ ) The period of treatment. Arrows indicate the onset of puberty in each group: (O) control; $(0)$ testosterone propionate-treated and (•) GnRH-treated groups.

Western ligand blotting of IGFBPS

Western ligand blotting of bovine plasma revealed four distinct bands that specifically bound ${ }^{125}$ I-labelled IGF-I. Their molecular masses were, respectively, 45-54, 38, 28 and $24 \mathrm{kDa}$. In the control group, the onset of puberty was characterized by an increase from day $100(0.69 \pm 0.14$ units $)$ to day 150 (1.72 \pm 0.21 units $)(P<0.001)$ in the intensity of the doublet
$45-54 \mathrm{kDa}$ band, which was identified as IGFBP-3, after which it remained constant until the end of the experiment (Fig. 2a). The intensity of the IGFBP-2 (38 kDa) band was markedly reduced from day 120 ( $0.67 \pm 0.18$ units) to day 160 $(0.17 \pm 0.08$ units $)(P<0.001)$ and remained low until the end of the experiment (Fig. 2b). During this period, no variations were observed for the $28 \mathrm{kDa}$ and $24 \mathrm{kDa}$ bands, 
(a)

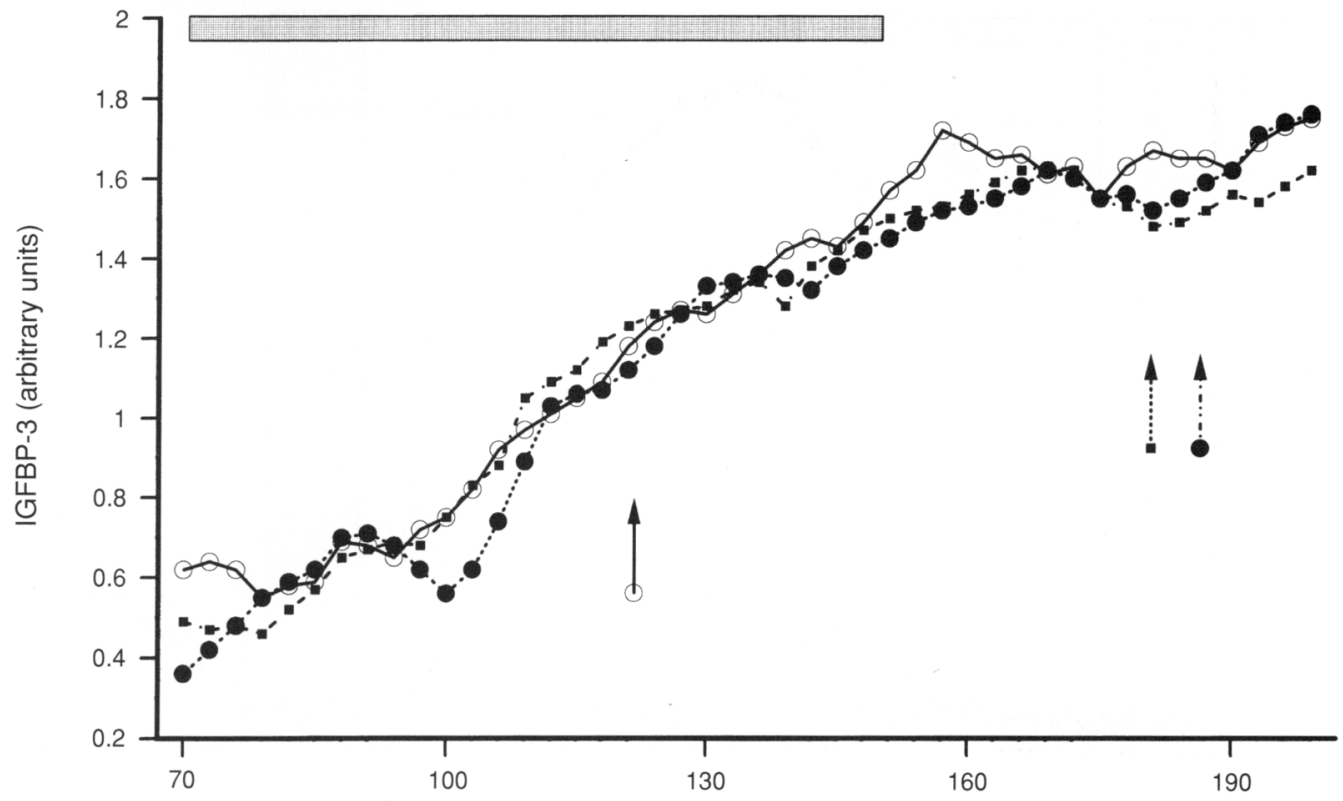

(b)

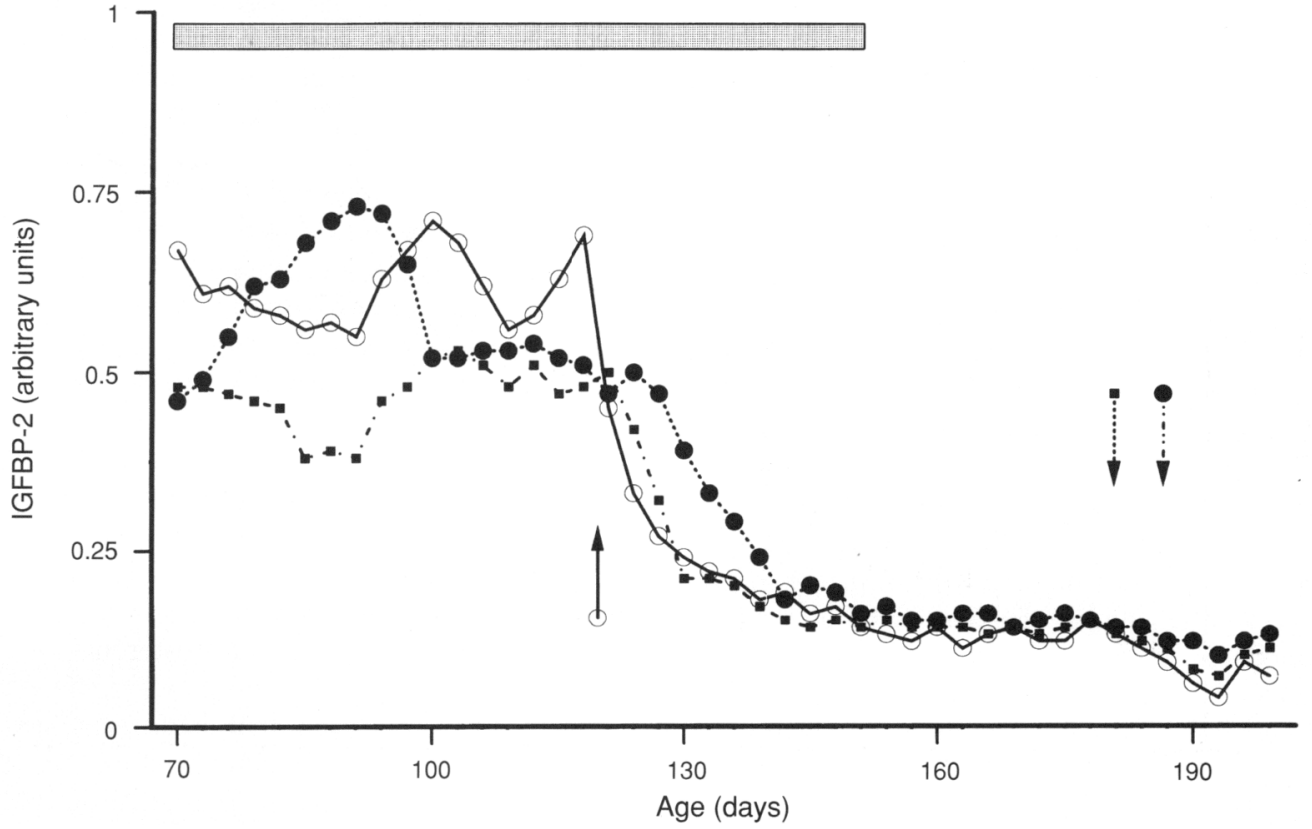

Fig. 2. Mean plasma concentration of (a) insulin-like growth factor-binding protein-3 (IGFBP-3) and (b) IGFBP-2 in $(O)$ control, (O) testosterone propionate-treated and (-) GnRH-treated groups during the onset of puberty.

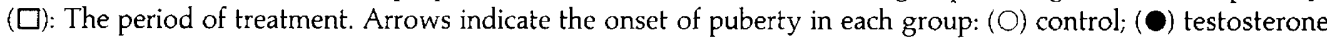
propionate-treated and $(\bullet)$ GnRH-treated groups.

corresponding to IGFBP-I and IGFBP-4, respectively (data not shown).

Daily injections of testosterone propionate or $\mathrm{GnRH}$ had no effect on mean plasma concentrations of IGFBP-2 and IGFBP-3. Indeed, the profile of these two proteins was similar to that reported for the control group, with a progressive increase in IGFBP-3 from about day 100 and a sharp decrease in IGFBP-2 after day 120 in both groups. No significant difference
$(P>0.05)$ was observed on any day of collection between the values in control and treated groups.

Immunoblotting of IGFBP-2 and IGFBP-3

The immunoblot method, using monoclonal antibodies against bovine IGFBP-2 and IGFBP-3, showed a similar pattern 

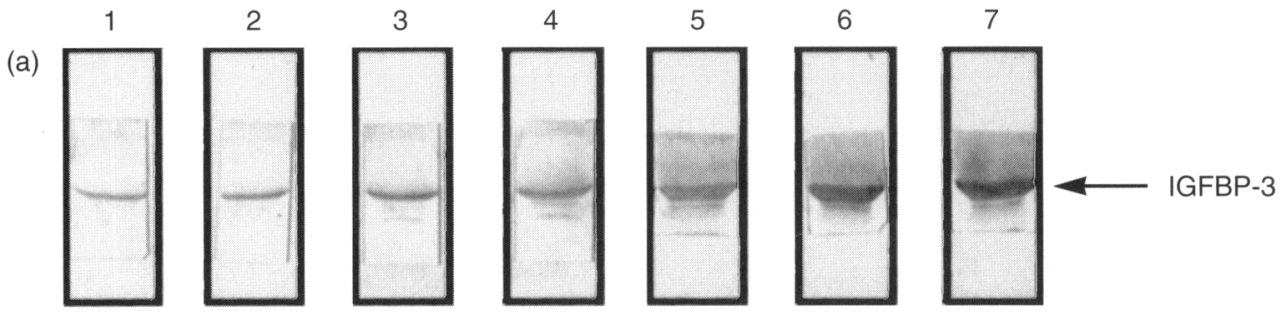

(b)
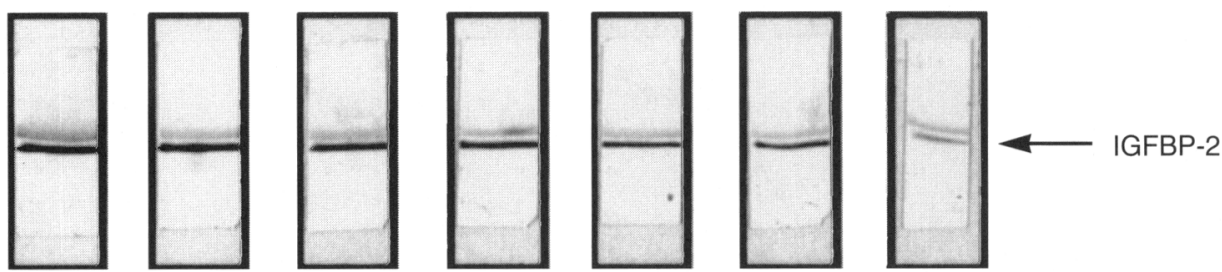

Fig. 3. (a) Plasma insulin-like growth factor binding protein-3 (IGFBP-3) and (b) IGFBP-2 in an individual bull calf 3 weeks before (lanes I-3) and three weeks after (lanes 5-7) puberty. Lane 4 represents the week during which the animal attained puberty (pulsatile release of testosterone). The proteins were revealed using monoclonal antibodies against bovine IGFBP-3 or IGFBP-2.

for these two proteins throughout the experimental period (Fig. 3) and was in agreement with data obtained using western ligand blotting.

\section{Discussion}

The study reported here was conducted to define the relationship between plasma concentrations of testosterone and IGF-I during puberty, by treating male calves with $\mathrm{GnRH}$ or testosterone propionate. In the control group, the onset of puberty in bull calves was identified by concomitant rises of plasma concentrations of testosterone and IGF-I, as described by Ronge and Blum (1989a, b) and Renaville et al. (1993). It has been suggested by previous studies, particularly in humans (Kerrigan and Rogol, 1992; Zachmann, 1992; Metzger et al., 1994), that these coordinated hormonal increases are driven by growth hormone. Indeed, data from the control group in the present study suggests that the puberty-associated increase in plasma concentrations of IGF-I could result from the stimulatory effect of testosterone on the somatotrophic axis, indirectly mediated via the oestrogen receptor after the aromatization of testosterone to oestradiol. Schwarz et al. (1992) reported that gonadectomy in cattle causes a fall in plasma concentrations of GH, testosterone and IGF-I and Metzer and Kerrigan (1994) showed that blocking the oestrogen receptor with tamoxifen results in decreased $24 \mathrm{~h}$ mean serum GH and plasma IGF-I in humans. However, Metzger et al. (1994) concluded that it is difficult to differentiate between the testosterone effects because the hormone can act either directly through the androgen receptor or indirectly through the oestrogen receptor once it is aromatized to oestrogen.

Under the experimental conditions in the present study, hormonal treatment of prepubertal bulls inhibited endogenous testosterone production. The partial suppression of gonadal steroidogenesis by GnRH (a prepubertal level was maintained) observed in this study are in agreement with previous reports in men (Harris et al., 1985; Styne et al,, 1985), rams (Lincoln et al, 1986) and stags (Lincoln, 1987) but are in conflict with studies in mature bulls (Rechenberg et al., 1986; Ronayme et al., 1993). Mann et al. (1984) reported that chronic administration of agonist analogues of GnRH induced a desensitization of the pituitary gonadotroph in rhesus monkeys. These authors also reported that infusion of a $\mathrm{GnRH}$ agonist in newborn rhesus monkeys suppressed the expected prepubertal increase in $\mathrm{LH}$ and testosterone (Mann et al., 1989). In rats, the postnatal increase in testosterone could be abolished by treatment with either GnRH agonist or antagonist (Kolho and Huhtaniemi, 1989). Several studies have also emphasized the relationship between testosterone and a variety of steroid growth promoters. It was observed (Fabry et al., 1983, 1984; Jones et al., 1991; Godfrey et al., 1992) that the pulsatile nature of testosterone profiles was abolished, testosterone secretion markedly reduced (but not suppressed) and puberty delayed after treatment with androgen, progestagen or oestrogen alone or in combination. In the present study, the sharp testosterone decrease observed in the testosterone-treated group after the end of treatment confirmed that endogenous testosterone synthesis was at a prepubertal level.

There are few studies that have examined the effects of testosterone or GnRH administration on the production of IGF-I in prepubertal males. Schwarz et al. (1992) observed no difference in plasma IGF-I profiles between bulls castrated before puberty (gonadectomy at 108 days of age) and intact bulls until approximately 250 days of age. In the present trial, although major inhibition of the secretion of endogenous testosterone took place during both hormonal treatments, there was no major alteration in IGF-I profiles during the onset of puberty in the two treatment groups when compared with the control group. The aim of the present study was to determine by which pathways IGF-I was modified by GnRH or testosterone treatment. The first observation in the present trial was that, contrary to the situation in castrated animals, the inhibition of endogenous testosterone synthesis in the GnRH- and testosterone-treated groups was not complete. Testosterone concentrations could therefore have been sufficient to induce 
the IGF-I surge at puberty. However, since testosterone treatment did not induce an increase in IGF-I, it is possible that the enzymes necessary to aromatize testosterone to oestradiol, which is known to induce a growth hormone-induced IGF-I response in cattle (Breier et al., 1988), are only present at puberty. Another possibility was suggested by Hobbs et al. (1993) who observed different effects of treatment with nandrolone and testosterone enanthate on IGF-I synthesis by a qualitative difference in androgenic potency at the neuroendocrine level, particularly if local $5 \alpha$-reduction of the androgen occurs. However, Tenover and Matsumoto (1992) found no change in either growth hormone or IGF-I values in young adult men treated with testosterone enanthate for 12 weeks.

Low IGF-I values from day 145 to day 155 in the treated groups could also indicate that testosterone synthesis was insufficient to sustain normal IGF production via oestrogen receptors and stimulation by growth hormone, as reported in steers by Schwarz et al. (1992). This hypothesis is also supported by the IGF-I increase noted in the present study after the physiological induction of a pulsatile testosterone release in both treatment groups.

IGFs in plasma and most body fluids are complexed with high-affinity binding proteins (IGFBPs). Numerous studies on nutritional status or treatment with growth hormone have clearly demonstrated that IGFBP-3, the predominant IGFBP in plasma, is relevant to the pharmacokinetics and action of IGF-I, while there is a negative correlation between IGFBP-2 and IGF-I concentrations (Cohick et al., 1992; Thissen et al., 1994). Taking into account this information, the results of our previous study (Renaville et al., 1993) and the data observed by Lee et al. (1991b) in pigs, the transition from puberty to maturity in bull calves may be identified by a marked decrease in IGFBP-2 and by an increase in IGFBP-3.

This is the first report of the use of specific monoclonal antibodies against bovine IGFBP-2 and IGFBP-3 in immunoblotting to confirm the changes in plasma concentrations of IGFBP- 2 and IGFBP-3 observed by western ligand blotting. As was observed for IGF-I, plasma concentrations of IGFBP-2 and IGFBP-3 in treated animals followed the profile reported for the control group and appeared unaffected by testosterone status.

In conclusion, our study shows that the abolition of the pubertal rise in plasma testosterone, by treatment with GnRH or testosterone propionate, does not have a marked effect on IGF-I or on its plasma-binding proteins (IGFBP-2 and IGFBP-3) in male calves. However, our results suggest that testosterone can still stimulate IGF-I synthesis, as observed in both treatment groups between days 180 and 190, when endogenous plasma concentrations of testosterone are increased. We therefore consider: (1) that the pubertal androgen surge is not the major factor responsible for the simultaneous increase in IGF-I and (2), that testosterone and IGF-I values increase simultaneously, but individually, at the onset of puberty in bulls. Further investigations are needed to understand the mechanism by which the synthesis of IGF-I and testosterone are induced at puberty.

Financial support for this study was provided by the Institut pour l'Encouragement de la Recherche Scientifique dans l'Industrie et l'Agriculture (research grants $5512 \mathrm{~A}$ and $5645 \mathrm{~A}$ ) and by Pôle d'Attraction Interuniversitaire research grant PAI 15. The authors wish to thank Y. Braet, R-M. Maistriaux and G. Tavernier for their technical assistance and J. Moreman for her help in the preparation of the manuscript.

\section{References}

Attie KM, Ramirez NR, Conte FA, Kaplan SL and Grumbach MM (1990) The prepubertal growth spurt in eight patients with true precocious puberty and growth hormone deficiency: evidence for a direct role of sex steroids Journal of Clinical Endocrinology and Metabolism 71 975-983

Breier BH, Gluckman PD and Bass JJ (1988) The somatotrophic axis in young steers: influence of nutritional status and oestradiol-17 $\beta$ on hepatic high and low-affinity somatotrophic binding sites Journal of Endocrinology 116 169-177

Breier BH, Gallaher BW and Gluckman PD (1991) Radioimmunoassay for insulin-like growth factor-I: solutions to some potential problems and pitfalls Journal of Endocrinology 128 347-357

Bruck C, Mathot S, Portetelle D, Berte C, Franssen JD, Herion P and Burny A (1982) Monoclonal antibodies define eight independent antigenic regions on the bovine leukemia virus (BLV) envelope glycoprotein gp51 Virology 122 342-352

Cohick WS, McGuire MA, Clemmons DR and Bauman DE (1992) Regulation of insulin-like growth factor-binding proteins in serum and lymph of lactating cows by somatotropin Endocrinology 130 1508-1514

Crawford BA, Singh J, Simpson JM and Handelsman DJ (1993) Androgen regulation of circulating insulin-like growth factor-I during puberty in male hypogonadal mice Journal of Endocrinology 139 57-65

Crawford BA, Simpson JM and Handelsman DJ (1994) Regulation of circulating IGF-I levels during puberty in male baboons (Papio hamadryas) Growth Regulation 4 (Supplement 1) 111 (Abstract)

Fabry J, Renaville R, Halleux V and Burny A (1983) Plasma testosterone and LH responses to $\mathrm{LHRH}$ in doubled-muscled bulls treated with trenbolone acetate and zeranol Journal of Animal Science 57 1138-1145

Fabry J, Renaville R and Burny A (1984) Blood plasma LH and testosterone concentration in anabolized bulls Animal Production 39 345-354

Godfrey RW, Lunstra DD and Schanbacher BD (1992) Effect of implanting bull calves with testosterone propionate, dihydrotestosterone propionate or oestradiol-17 $\beta$ prepubertally on the pituitary-testicular axis and on postpubertal social and sexual behaviour Journal of Reproduction and Ferfility 94 $57-69$

Harris DA, Van Vliet G, Egli CA, Grumbach MM, Kaplan SL, Styne DM and Vainsel M (1985) Somatomedin-C in normal puberty and in true precocious puberty before and after treatment with a potent luteinizing hormonereleasing hormone agonist Journal of Clinical Endocrinology and Metabolism $61152-159$

Hobbs CJ, Plymate SR, Rosen CJ and Adler RA (1993) Testosterone administration increases insulin-like growth factor-l levels in normal men Joumal of Clinical Endocrinology and Metabolism 77 776-779

Jasper HG (1985) Somatomedin response to testosterone stimulation in children with male pseudohermaphroditism, cryptorchidism, anorchia, or micropenis Journal of Clinical Endocrinology and Metabolism 60910913

Jones SJ, Johnson RD, Calkins CR and Dikeman ME (1991) Effects of trenbolone acetate on carcass characteristic and serum testosterone and cortisol concentrations in bulls and steers on different management and implant schemes Journal of Animal Science 69 1363-1369

Kerrigan JR and Rogol AD (1992) The impact of gonadal steroid hormone action on growth hormone secretion during childhood and adolescence Endocrine Revietos 13 281-298

Kolho KL and Huhtaniemi I (1989) Suppression of pituitary-testis function in rats treated neonatally with a gonadotrophin-releasing hormone agonist and antagonist: acute and long-term effects Journal of Endocrinology 123 83-91

Lee CY, Bazer FW, Etherton TD and Simmen FA (1991a) Ontogeny of insulinlike growth factors (IGF-I and IGF-II) and IGF-binding proteins in porcine serum during fetal and postnatal development Endocrinology 128 2336-2344

Lee CY, Hunt DW, Gray SL and Henricks DM (1991b) Secretory patterns of growth hormone and insulin-like growth factor-I during peripubertal period in intact and castrated male cattle Domestic Animal Endocrinology 8 48I-489

Lemal D, Renaville R, Claes V, Ruelle L, Fabry J, Burny A, Underwood LE and Ketelslegers JM (1989) Effect of pituitary somatotropin injections on plasma insulin-like growth factor-I and growth hormone profiles in growing heifers Journal of Animal Science $672715-2723$ 
Lincoln GA (1987) Long-term stimulatory effects of a continuous infusion of LHRH agonist on testicular function in male red deer (Cervus elaphus) Journal of Reproduction and Fertility $\mathbf{8 0} 257-261$

Lincoln GA, Fraser HM and Abbott MP (1986) Blockage of pulsatile LH, FSH and testosterone secretion in rams by constant infusion of an LHRH agonist Journal of Reproduction and Fertility 77 587-597

Lord APD, Martin AA, Walton PE, Ballard FJ and Read LC (1991) Insulin-like growth factor-binding proteins in tissue fluids from the lamb lournal of Endocrinology 129 59-68

Mann DR, Gould KG and Collins DC (1984) Influence of continuous gonadotropin-releasing hormone $(\mathrm{GnRH})$ agonist treatment on luteinizing hormone and testosterone secretion, the response to $\mathrm{GnRH}$, and the testicular response to human chorionic gonadotropin in male rhesus monkeys Journal of Clinical Endocrinology and Metabolism 58 262-267

Mann DR, Gould KG, Collins DC and Wallen K (1989) Blockage of neonatal activation of the pituitary-testicular axis: effect on peripubertal luteinizing hormone and testosterone secretion and on testicular development in male monkeys Journal of Clinical Endocrinology and Metabolism $\mathbf{6 0}$ $600-607$

Metzger DL and Kerrigan JR (1994) Estrogen receptor blockade with tamoxifen diminishes growth hormone secretion in boys: evidence for a stimulatory role of endogenous estrogens during male adolescence Journal of Clinical Endocrinology and Metabolism $79513-518$

Metzger DL, Kerrigan JR and Rogol AD (1994) Gonadal steroid hormone regulation of the somatotropic axis during puberty in humans: mechanisms of androgen and estrogen action. Trends in Endocrinology and Metabolism 5 290-296

Mirza I, Wilkin T, Cantarini M and Moore K (1987) A comparison of spleen and lymph node cells as fusion partners for the raising of monoclonal antibodies after different routes of immunization Journal of Immunology Methods 105 235-243

Parker CW (1990) Radiolabelling of proteins Methods in Enzymology 182 $721-737$

Portetelle D, Dandoy C, Burny A, Zavada J, Siakkou H, Gras-Masse H, Drobecq H and Tartar A (1989) Synthetic peptides approach to identification of epitopes on Bovine Leukemia Virus envelope glycoprotein gp5 I Virology 169 34-4I

Portetelle D, Massart S, Sneyers M, Burny A and Renaville R (1995) Monoclonal antibodies to bovine insulin-like growth factor-binding protein-2 and -3 : production and preliminary characterization Symposium on Hormone Binding Proteins: Physiology and Clinical Implications. $78^{\circ}$ Journées Internationales Henri-Pierre Klotz d'Endocrinologie Clinique, Paris p58 (Abstract)
Rechenberg WV, Sandow J and Klatt P (1986) Effect of long-term infusion of an LH-releasing hormone agonist on testicular function in bulls Journal of Endocrinology 109 R9-RII

Renaville R, Fabry J, Halleux V and Burny A (1983) Testosterone plasma profiles, as a function of age in young bulls from the bovine double-muscled Belgian White Blue breed. A preliminary report Theriogenology 19 159-167

Renaville R, Devolder A, Massart S, Sneyers M, Burny A and Portetelle D (1993) Changes in the hypophysial-gonadal axis during the onset of puberty in young bulls journal of Reproduction and Fertility 99 443-449

Ronayme E, Enright WJ and Roche JF (1993) Effects of continuous administration of gonadotropin-releasing hormone $(\mathrm{GnRH})$ or a potent $\mathrm{GnRH}$ analogue on blood luteinizing hormone and testosterone concentrations in prepubertal bulls Domestic Animal Endocrinology 10 179-189

Ronge $\mathbf{H}$ and Blum JW (1989a) Insulin-like growth factor-I during growth in bulls Reproduction Nutrition Developpement 29 105-III

Ronge $\mathbf{H}$ and Blum JW (1989b) Insulin-like growth factor-I binding proteins in dairy cows, calves and bulls Acta Endocrinologica 121 153-160

SAS (1991) SAS User's Guide: Statistics (Version 6), SAS Institute, Inc, Cary, NC

Schwarz FJ, Röpke R, Schams D and Kirchgessner M (1992) Effects of sex and growth on plasma concentrations of growth hormone, insulin-like growth factor-I and insulin in fattening simmental cattle Journal of Animal Physiology and Animal Nutrition 68 263-271

Smith WJ, Nam TJ, Underwood LE, Busby WH, Celnicker A and Clemmons DR (1993) Use of insulin-like growth factor-binding protein-2 (IGFBP-2), IGFBP-3, and IGF-I for assessing growth hormone status in short children Journal of Clinical Endocrinology and Metabolism 77 1294-1299

Styne DM, Harris DA, Egli CA, Conte FA, Kaplan SL, Rivier J, Vale W and Grumbach MM (1985) Treatment of true precocious puberty with a potent luteinizing hormone-releasing hormone agonist: effect of growth sexual maturation, pelvic sonography and the hypothalamic-pituitary-gonadal axis Journal of Clinical Endocrinology and Metabolism 65 142-149

Tenover IS and Matsumoto AM (1992) Effect of testosterone (T) on growth hormone $(\mathrm{GH})$ and insulin-like growth factor-I levels in healthy elderly and young adult men. 74th Annual Meeting of the Endocrine Society page 367 (Abstract)

Thissen JP, Ketelslegers JM and Underwood LE (I994) Nutritional regulation of the insulin-like growth factors Endocrine Reviews 15 80-10I

Zachmann M (1992) Interrelations between growth hormone and sex hormones: physiology and therapeutic consequences. Hormone Research $\mathbf{3 8}$ (Supplement 1) 1-8 